\title{
An Altered Invertase in the cot-2 Mutant of Neurospora crassa
}

\author{
By CAROLINE EGGERDING,* JUDITH A. RANDALL AND \\ M. L. SARGENT \\ Department of Botany, University of Illinois, Urbana, Illinois 61801, U.S.A.
}

(Received 17 December 1974; revised 4 February 1975)

\begin{abstract}
SUMMARY
Because the cot-2 and inv loci of Neurospora crassa are closely linked, the invertase from the morphological mutant, cot-2, was examined. The cot-2 strains produce an invertase with altered heat sensitivity, $K_{\mathrm{m}}$, and ratio of heavy to light forms. The cellular localization of cot-2 invertase is different from that of the wild type. There were no observable changes in the energy of activation or the $\mathrm{pH}$ optimum of cot-2 invertase, and some of the differences detected were not apparent under culture conditions that promoted wild-type growth. Since recombination (about $5 \%$ ) occurred between $\cot -2$ and inv and culture conditions affected the enzyme characteristics, we suggest cot-2 determines, in part, the carbohydrate composition of the enzyme.
\end{abstract}

\section{INTRODUCTION}

Morphological mutants of Neurospora crassa are excellent test systems for studying the effects of gene action on morphology. These strains combine the simplicity of single-gene mutations with drastically altered physical form. Primary enzyme deficiencies are known for I I such mutants, eight of which cause alterations in the area of carbohydrate metabolism involving glucose-6-phosphate (Brody, 1973).

Brody \& Tatum (1966) found that the colonial morphology of the col-2 strain is the result of a defective glucose-6-phosphate dehydrogenase (G-6-PD) and were the first to use this approach for studying morphogenesis in Neurospora. Subsequently, two other mutants, balloon and frost, were shown to possess a defective G-6-PD activity (Scott \& Tatum, 1970). A defective 6-phosphogluconic acid dehydrogenase, another enzyme in the hexose monophosphate shunt, has been found in col-3 and col-1o (Lechner \& Fuscaldo, I969; Abramsky, Scott \& Tatum, I97I; Fuscaldo, Lechner \& Bazinet, I97I ; Lechner, Fuscaldo \& Bazinet, 197I). The ragged-I and ragged-2 mutants studied by Brody \& Tatum (1967) and Mishra \& Tatum (1970) possess an altered phosphoglucomutase. As a final example, there is a morphological mutant studied by Murayama (1969) with an altered phosphohexoseisomerase. The three other morphological mutants for which enzyme deficiencies are known possess altered phospholipid metabolism (Crocken \& Nyc, I964; Pina \& Tatum, 1967; Scarborough \& Nyc, 1967).

cot-2, a morphological mutant of $N$. crassa, is characterized by colonial growth at $34{ }^{\circ} \mathrm{C}$ and near wild-type growth at $25^{\circ} \mathrm{C}$ (Garnjobst \& Tatum, 1967). cot-2 is located 48 map units distal to the centromere in linkage group V (Morgan, Garnjobst \& Tatum, 1967). Interest in the primary biochemical defect responsible for the cot-2 morphology was stimulated when Sargent \& Woodward $(1969 b)$ discovered and mapped the inv gene in the timex strain of $N$. crassa. This gene, a structural gene for invertase ( $\beta$-D-fructofuranoside

* Present address: Washington University School of Medicine, St Louis, Missouri 63I Io, U.S.A. 
fructohydrolase, EC. 3.2.I.32), maps at approximately the same location as cot-2 in the right arm of group $\mathrm{V}$.

The problem, then, was to determine if an altered invertase is responsible for the cot-2 morphology. The approximate frequency of genetic recombination between $\cot -2$ and inv was determined. The cot-2 and wild-type invertases were compared biochemically using such parameters as $K_{\mathrm{m}}$, energy of activation $\left(\mathrm{E}_{\mathrm{a}}\right), \mathrm{pH}$ optimum, thermolability, localization and specific activity. In addition, the physical structures of the two invertases were compared in a preliminary way by disc-gel electrophoresis and column chromatography.

\section{METHODS}

Strains and growth conditions. Neurospora crassa 74-OR23-IA (FGSC987, Fungal Genetics Stock Center, Humbolt State College, Arcata, California, U.S.A.) was used as the wild-type control. The original cot-2a, RIO06 (FGSCI5I2), was backcrossed (Davis \& de Serres, 1970) seven times to the wild-type strain to provide an isogenic background. The sets of isolates from each backcross were numbered MLS42-X to MLS48-X, consecutively. Ascospores from each cross were randomly isolated, heat shocked at $60^{\circ} \mathrm{C}$ for $30 \mathrm{~min}$ and incubated at $34^{\circ} \mathrm{C}$ after germination to identify the cot-2 progeny. Strains used for most biochemical studies on cot-2 invertase were 45-I, 47-8, and 48-I. Procedures for stock maintenance have been reported (Sargent \& Woodward, 1969a).

An invertaseless strain, inv, al, thi, A (MLS49-I) and a strain cot-2, al, thi, a (MLS50-I) were constructed in preparation for determining the inv $\times \cot -2$ recombination frequency. After the two strains were crossed, ascospores were collected, heat-shocked and plated on a medium containing $3 \%(\mathrm{w} / \mathrm{v})$ sorbose, $0.2 \%$ fructose, $0.02 \%$ thiamine, $1.5 \%$ agar, and IX Vogel's salts (Vogel, I964). The $\cot ^{+}$inv $^{+}$recombinant colonies were identified by germination at $35^{\circ} \mathrm{C}$, in vivo invertase activity (Sargent \& Braymer, 1969) and albino pigmentation.

Mycelia were grown in a minimal-fructose medium (IX Vogel's salts and $\mathrm{I} \cdot 5 \%$ fructose) inoculated with $10^{5}$ conidia/ml. All cultures were grown at $25^{\circ} \mathrm{C}$ for $72 \mathrm{~h}$ unless stated otherwise. Shake cultures $(800 \mathrm{ml}$; linear growth) were incubated on a reciprocal shaker at I00 strokes/min. Bubble cultures ( $1600 \mathrm{ml}$; exponential growth) were vigorously aerated and harvested at a density of $\mathrm{I} \mathrm{mg}$ dry wt mycelium $/ \mathrm{ml}$ medium. In all cases, the mycelia were harvested by filtration and washed with cold $\left(4^{\circ} \mathrm{C}\right)$ water. The mycelia were immediately lyophilized, ground in a Wiley Mill using a 60-mesh screen, and stored at $-20^{\circ} \mathrm{C}$.

Assay procedures. Crude extracts were prepared by shaking mycelial powder $(50 \mathrm{mg} / \mathrm{ml}$ unless otherwise stated) with $50 \mathrm{~mm}$-sodium acetate buffer $\mathrm{pH} 5.0$ at $4{ }^{\circ} \mathrm{C}$ for $\mathrm{I} \mathrm{h}$. The mixture was then centrifuged for $20 \mathrm{~min}$ at $20000 \mathrm{~g}$ to remove cell debris, and the supernatant fraction (crude extract) collected. Total mycelial activity was determined by assaying the extracts before clarification, while soluble activity was determined from suitable dilutions of the crude extract. Exoenzyme levels were measured by assaying samples of the culture media that had been dialysed for $24 \mathrm{~h}$ against three changes of distilled water at $4{ }^{\circ} \mathrm{C}$.

Three different fixed-time assays were used to measure invertase activity. The usual method was that in Experimental Biochemistry (1964) modified by increasing the reaction temperature from 25 to $37{ }^{\circ} \mathrm{C}$ and decreasing the final assay volume to $15 \mathrm{ml}$. A more sensitive, but less convenient, method based on Metzenberg (1962) and Somogyi (1952) has been described (Sargent \& Woodward, 1969a), and was used when necessary. When excess fructose interfered with the colorimetric reaction, the Glucostat $4 \mathrm{X}$ reagent (Worthington Biochemical Corp.) was used specifically to measure glucose formation (Sargent \& 
Woodward, $1969 b$ ). A unit of activity is defined as that amount of enzyme that will cleave I $\mu \mathrm{mol}$ sucrose/min under the stated assay conditions. Specific activity refers to units of activity/mg dry wt mycelium unless otherwise stated. Most experiments were repeated several times and enzyme assays were done in duplicate using different enzyme concentrations.

The method of Lowry et al. (I95I) was employed to determine protein concentration using bovine serum albumin (Sigma) as a standard.

Enzyme kinetics. Heat sensitivity of invertase was determined by placing covered tubes of appropriately diluted crude extract into a water bath at $55{ }^{\circ} \mathrm{C}$. Portions were removed at suitable intervals, placed on ice, and subsequently assayed for invertase activity. The method of Clark (Experimental Biochemistry, 1964) was employed to determine the Michaelis-Menton constant, $K_{\mathrm{m}}$, from a Lineweaver-Burk plot. The energy of activation was determined by assaying crude extracts at several temperatures, and measuring the slope from an Arrhenius plot of the data. Activity as a function of $\mathrm{pH}$ was measured by making crude extracts with several different buffers $(50 \mathrm{mg} / \mathrm{ml})$ and using these buffers in the assay system (Metzenberg, I963a).

Chromatography and electrophoresis. Separation of invertase forms on the basis of size was accomplished by Sephadex column chromatography (Metzenberg, 1964). All procedures were carried out at $4{ }^{\circ} \mathrm{C}$ in a $2 \times 35 \mathrm{~cm}$ column using $50 \mathrm{~mm}$-tris- $\mathrm{HCl} \mathrm{pH} 7.5$ as the elutant buffer. A $2 \mathrm{ml}$ sample was applied to the top of the column under a $2 \mathrm{~cm}$ layer of buffer, and the effluent collected in approximately $2 \mathrm{ml}$ samples for assay of invertase activity.

Polyacrylamide-gel disc electrophoresis (Davis, I964) was used to examine crude extracts, purified invertase, and exoenzymes present in the growth medium. No spacer or sample gel was used. The running gel was made from $6 \%(\mathrm{w} / \mathrm{v})$ acrylamide and $0 \cdot 2 \% N, N^{\prime}$-methylenebis-acrylamide. Polymerization was initiated by the addition of $0.14 \%$ ammonium persulphate and $0.06 \% N, N, N^{\prime}, N^{\prime}$-tetramethyleneethylenediamine and the gels were allowed to polymerize for $\mathrm{I} h$ before use. Various buffers, including tris-glycine at $\mathrm{pH} 8 \cdot 3$ (Davis, 1964) and 50 mM-tris- $\mathrm{HCl}$ at $\mathrm{pH}$ values $7 \cdot 2,7 \cdot 3$ and $7 \cdot 5$, were employed in the running gels, with the former usually giving the best results.

Crude extracts were mixed ( $\mathrm{I}: \mathrm{I}, \mathrm{v} / \mathrm{v}$ ) with $10 \%(\mathrm{v} / \mathrm{v})$ glycerol, and $\mathrm{I} 0 \mu \mathrm{l}$ samples containing $50 \mu \mathrm{g}$ protein were applied to the gels. To study exoenzymes, media samples dialysed as before were concentrated using a flash evaporator $\left(42{ }^{\circ} \mathrm{C}\right)$ until $2 \%$ of the original volume remained. Samples containing $20 \mu \mathrm{g}$ protein were applied to the gels as before. The tracking dye was $0.05 \%$ bromophenol blue; one drop was mixed with the sample before application. Gels were run $\mathrm{I} \mathrm{h}$ at $4{ }^{\circ} \mathrm{C}$ and $2.5 \mathrm{~mA}$.

Invertase activity in the gels was detected by placing them in $4.0 \mathrm{M}$-sodium acetate buffer pH $5^{\circ} \mathrm{O}$ containing I M-sucrose, and incubating for $10 \mathrm{~min}$ at $37^{\circ} \mathrm{C}$. After the gels were washed in distilled water, the invertase activity was localized by a colorimetric reaction (Gabriel \& Wang, 1969) for liberated fructose. The stained gels were washed and stored in $7.5 \%(\mathrm{v} / \mathrm{v})$ acetic acid, and scanned at $360 \mathrm{~nm}$ in a Gilford spectrophotometer with a linear transport system. A polar planimeter (Keuffel and Esser Co.) was used for curve integration.

\section{RESULTS}

Allelism test between inv and cot-2

To determine whether the inv and cot-2 genes were allelic, a cross was made between an inv, al, thi strain and a cot-2, al, thi strain. Of the $2057 \cot ^{+}$colonies tested from random platings, IOI proved to be $\cot ^{+}, i n v^{+}$, thereby yielding a recombination frequency of about $4.9 \%$. The cross was not fully fertile as the germination rate was about $30 \%$. Crosses 
Table I. Level and location of invertase activity

\begin{tabular}{|c|c|c|c|c|c|}
\hline \multirow[b]{2}{*}{ Strain } & \multirow{2}{*}{$\begin{array}{c}\text { Growth } \\
\text { temperature } \\
\left({ }^{\circ} \mathrm{C}\right)\end{array}$} & \multicolumn{4}{|c|}{ Invertase specific activity* } \\
\hline & & Total & Soluble & Wall-bound & Extracellular \\
\hline \multicolumn{6}{|l|}{ Shake culture } \\
\hline Wild type & 25 & I. $68(100)$ & 0.2 I $(12.4)$ & $I \cdot 46(86 \cdot 8)$ & $0.015(0.8)$ \\
\hline $\cot -2\left(4^{8}-I\right)$ & 25 & I. $40(100)$ & $0.34(24 \cdot 5)$ & $I \cdot 05(75 \cdot 1)$ & $0.005(0.4)$ \\
\hline $\cot -2(48-1)$ & 34 & $2 \cdot 15(100)$ & $0.74(34 \cdot 2)$ & $1.41(65 \cdot 2)$ & $0.012(0.6)$ \\
\hline \multicolumn{6}{|l|}{ Bubble culture } \\
\hline Wild type & 25 & $\mathrm{I} \cdot 79(100)$ & $I \cdot 20(67 \cdot I)$ & $0.54(29.9)$ & $0.054(3.0)$ \\
\hline $\cot -2(\mathrm{R} I 006)$ & 25 & $3.04(100)$ & $I \cdot 56(40 \cdot 8)$ & $0.89(43 \cdot 8)$ & $0.592(15.4)$ \\
\hline $\cot -2(47-8)$ & 25 & $\mathrm{I} \cdot 88(100)$ & $0.59(3 I \cdot 4)$ & $I \cdot 00(53 \cdot 0)$ & $0.293(15.6)$ \\
\hline $\cot -2(48-I)$ & 25 & $2 \cdot 56(100)$ & $0.95(36.9)$ & $I \cdot 07(42 \cdot 2)$ & $0.535(20.9)$ \\
\hline
\end{tabular}

* Assays were done on unclarified mycelial suspensions, crude extracts, and the culture medium. Total activity equals the sum of the activities in the unclarified suspension and the culture medium. Soluble activity is that present in the crude extract, while wall-bound activity is obtained by subtracting the soluble activity from that in the unclarified suspension. Figures in parentheses represent percentages of the total activity.

involving cot-2 characteristically give a low germination rate in this laboratory, and $\cot -2 \times$ cot-2 crosses are known to yield round ascospores (Barry et al. 1972). If the low germination rate is accompanied by differential germination of various genotypes, the true recombination frequency may not be $4.9 \%$. It is clear, however, that the two genes are not allelic.

\section{Growth conditions, morphology and invertase localization}

In preliminary experiments it became clear that cot-2 morphology and invertase characteristics are both affected significantly by mycelial growth conditions. For example, after $72 \mathrm{~h}$ growth, wild-type mycelia from shake cultures were well dispersed with an average density of $2 \mathrm{mg}$ dry wt mycelium/ml medium. In contrast, cot-2 in such cultures at $25^{\circ} \mathrm{C}$ grew slowly and in the form of mycelial balls, even after very long growth periods. At higher restrictive temperatures, these mycelial balls were highly compact and adhered tightly to the sides of the flask.

Invertase specific activity and localization in $72 \mathrm{~h}$ shake cultures of cot-2 grown both at a permissive $\left(25^{\circ} \mathrm{C}\right)$ and restrictive $\left(34^{\circ} \mathrm{C}\right)$ temperature were compared with the wild-type control grown at $25^{\circ} \mathrm{C}$. The results (Table I) indicated that cot-2 grown at the restrictive temperature had the highest level of total activity, and that cot-2 had a lower proportion of the enzyme bound to the cell wall, especially at the restrictive temperature. The proportion of wild-type invertase that was wall-bound is comparable to that reported by Sargent \& Woodward (1969b) and Chang \& Trevithick (1972). In general, stationary cultures produced the same ratios of soluble to bound invertase as did the shake cultures.

In contrast to the above, mycelia from bubble cultures of both wild type and cot-2 were well dispersed and ready for harvesting after $24 \mathrm{~h}$ growth. As seen in Table I, growth in bubble cultures caused a reduction in the amount of wall-bound enzyme. In the wild-type strain the non-bound activity appeared primarily in the soluble fraction, whereas all three cot-2 strains released much of that activity into the medium. All four strains produced more extracellular invertase when grown in these aerated cultures; $3 \%$ of the total wild-type invertase was extracellular, while cot-2 strains liberated up to one-fifth of their total invertase activity into the medium.

The level of soluble invertase in crude extracts of cot-2 was expected to stabilize as the number of backcrosses increased. However, $72 \mathrm{~h}$ shake cultures of representatives from 


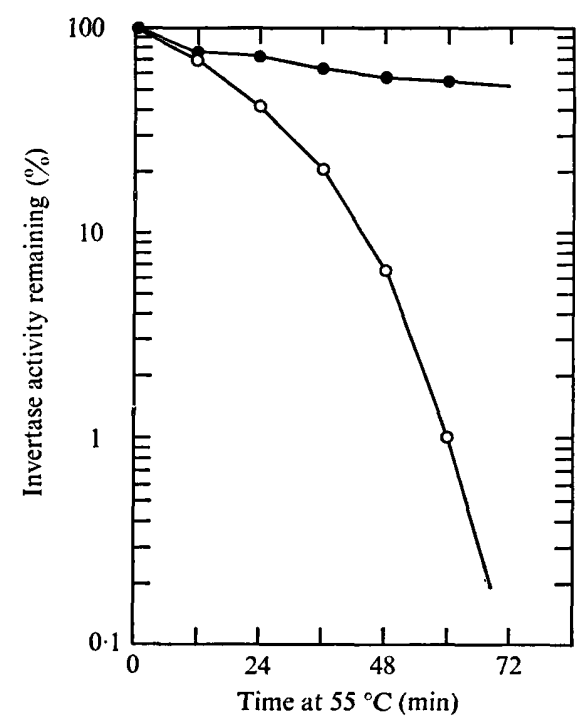

Fig. I. Heat sensitivity of invertase in crude extracts from shake cultures of $(\bullet)$ wild type and (O) $c o t-2(45-1)$ grown at $25^{\circ} \mathrm{C}$.

each backcross grown at the permissive temperature had different invertase specific activities (range 0.2 I to 0.34 units $/ \mathrm{mg}$ ) with no pattern being evident. It was shown that soluble invertase activity in cot-2 shake cultures varied with physiological age. However, there was still variation in invertase activity when the cot-2 backcross representatives were grown in bubble cultures and harvested at the same physiological age.

\section{Invertase heat sensitivity}

The thermolability of invertase from the original cot-2 strain (RIO06) in crude extracts from shake cultures grown at $25^{\circ} \mathrm{C}$ was slightly different from wild-type invertase at 50 and $60{ }^{\circ} \mathrm{C}$, but radically different at $55^{\circ} \mathrm{C}$ (Fig. I). Representatives from the first four backcrosses, and all fifth-backcross strains had similar heat-sensitive invertases which retained I to $8 \%$ of their original activity after $\mathrm{I} \mathrm{h}$ at $55^{\circ} \mathrm{C}$ (Table 2 ). Of the nine random isolates from the sixth backcross, only one (47-8), possessed a typically heat-sensitive invertase. The invertases of the remainder, including the parent strain (47-I) for the seventh backcross, displayed a heat sensitivity intermediate between that of the wild type and cot-2 (RIO06) enzymes. The five isolates of the seventh backcross were further modified, the heat sensitivity of their invertase approaching that of the wild type. The variability between experimental runs was possibly caused by small but critical flucuations in the water-bath temperature.

When crude extracts of cot-2 and wild type were diluted to give equal invertase activities, and then combined and assayed, the heat sensitivity of the mixture was intermediate in value. This suggested that the heat sensitivity observed in the cot-2 enzyme was not due to the absence or inactivation of some stabilizing molecule present in wild-type crude extracts. Metzenberg (1964) reported that light invertase $(5 \cdot 2 \mathrm{~S})$ is considerably more heat sensitive than heavy invertase (10.3 S; a tetramer), but that the cot-2 strains have, if anything, a higher proportion of the heavy invertase (see below); therefore an altered light/heavy ratio is not responsible for the increased heat sensitivity. 


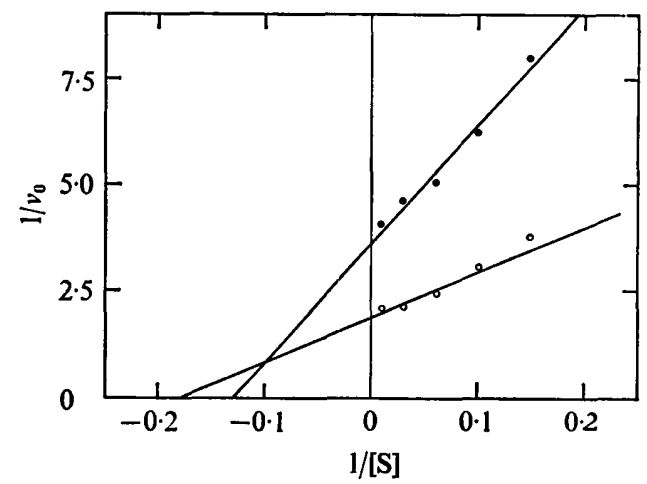

Fig. 2

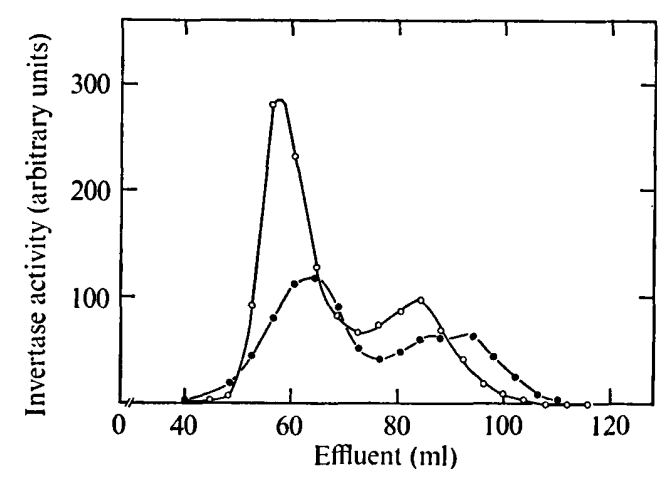

Fig. 3

Fig. 2. Lineweaver-Burk plot for invertase assayed at $37^{\circ} \mathrm{C}$ in crude extracts from shake cultures of (O) wild type and (O) $\cot -2(45-1)$ grown at $25^{\circ} \mathrm{C}$. [S] is in $\mu \mathrm{mol}$ sucrose $/ \mathrm{ml}$.

Fig. 3. Sephadex G 200 elution patterns of soluble invertase from shake cultures of (O) wild type and $(O) \cot -2(45-1)$ grown at $25^{\circ} \mathrm{C}$.

Table 2. Heat sensitivity of invertase from wild type and cot-2

Assays were done on crude extracts from shake cultures grown at $25^{\circ} \mathrm{C}$.

\begin{tabular}{|c|c|c|c|}
\hline \multirow[b]{2}{*}{ Strain } & \multicolumn{3}{|c|}{$\begin{array}{c}\text { Invertase specific activity remaining } \\
\text { after } \mathrm{I} \text { at } 55^{\circ} \mathrm{C}(\%)\end{array}$} \\
\hline & Expt I & Expt 2 & Expt 3 \\
\hline Wild type & $5 I \cdot 4$ & $70 \cdot 2$ & $5 \mathrm{I} \cdot 8$ \\
\hline $\begin{array}{l}\text { cot-2 } \\
\text { RI006 }\end{array}$ & $8 \cdot 1$ & - & - \\
\hline $42-I$ & $5 \cdot I$ & - & - \\
\hline $43^{-I}$ & $3 \cdot 8$ & - & - \\
\hline $44^{-I}$ & $3 \cdot 3$ & - & - \\
\hline $45-I$ & $6 \cdot 2$ & - & - \\
\hline $46-2$ & $3 \cdot 7$ & $4 \cdot 3$ & 18.6 \\
\hline $47-8$ & - & - & I 8.3 \\
\hline $47-I$ & $34 \cdot 2$ & 一 & - \\
\hline $47^{-2}$ & - & $30 \cdot 3$ & - \\
\hline $47-4$ & - & $35 \cdot 7$ & - \\
\hline $47-5$ & - & $36 \cdot 7$ & - \\
\hline $47-6$ & - & $39 \cdot 5$ & - \\
\hline $47-7$ & 一 & - & $34 \cdot 8$ \\
\hline $47-9$ & - & $27 \cdot 6$ & - \\
\hline $48-I$ & - & 一 & $42 \cdot 8$ \\
\hline $4^{8-2}$ & $45 \cdot 8$ & $66 \cdot I$ & $47 \cdot 4$ \\
\hline $48-3$ & - & $70 \cdot 3$ & $44 \cdot 4$ \\
\hline $48-4$ & - & $73 \cdot 0$ & $39 \cdot 7$ \\
\hline $48-5$ & - & - & $47 \cdot 7$ \\
\hline
\end{tabular}

Invertase $K_{\mathrm{m}}$ and $E_{\mathrm{a}}$

The $K_{\mathrm{m}}$ for cot-2 invertase, measured in crude extracts from material grown in shake cultures, was consistently different from that of the wild-type control (Fig. 2; Table 3). This difference, about a $30 \%$ decrease compared with wild type, was apparent for values obtained at three different temperatures, 25,37 and $45^{\circ} \mathrm{C}$ (Table 3). When the strains were grown in bubble cultures, however, the $K_{\mathrm{m}}$ of $\cot -2$ invertase resembled that of the wild-type control 
Table 3. $K_{\mathrm{m}}$ of invertase from wild type and cot-2

Assays were done on crude extracts from cultures grown at $25^{\circ} \mathrm{C}$.

\begin{tabular}{|c|c|c|}
\hline \multirow[b]{2}{*}{ Assays on different strains* } & \multicolumn{2}{|c|}{$K_{\mathrm{ln}}(\mathrm{mM})$} \\
\hline & $\begin{array}{l}\text { Shake } \\
\text { cultures }\end{array}$ & $\begin{array}{l}\text { Bubble } \\
\text { cultures }\end{array}$ \\
\hline $\begin{array}{l}\text { Wild type } \\
\text { cot-2 }(45-1) \\
\operatorname{cot-2}(48-1) \\
\operatorname{cot-2}(\text { R IOO6) } \\
\operatorname{cot-2}(47-8)\end{array}$ & $\begin{array}{l}7 \cdot 7 \\
5 \cdot 4 \\
5 \cdot 0 \\
- \\
-\end{array}$ & $\begin{array}{l}\frac{6 \cdot 4}{6 \cdot} \\
6 \cdot 5 \\
6 \cdot 2 \\
6 \cdot 5\end{array}$ \\
\hline \multirow{2}{*}{$\begin{array}{l}\text { Assays at different } \\
\text { temperatures }\left({ }^{\circ} \mathrm{C}\right) \dagger\end{array}$} & \multicolumn{2}{|c|}{$K_{\mathrm{m}}(\mathrm{mM})$} \\
\hline & Wild type & $\cot -2(48-1)$ \\
\hline 25 & $6 \cdot 0$ & $4 \cdot I$ \\
\hline 37 & $7 \cdot 7$ & 5.0 \\
\hline 45 & $9 \cdot 3$ & 6.4 \\
\hline
\end{tabular}

(Table 3). Metzenberg (1963a) reported $K_{\mathrm{m}}$ values at $37^{\circ} \mathrm{C}$ of $6 \cdot \mathrm{I} \mathrm{mm}$ for purified invertase (unspecified wild-type strain) and $6.6 \mathrm{~mm}$ for invertase in crude extracts. Our $K_{\mathrm{m}}$ values (6.2 and 6.5) from bubble cultures are similar to Metzenberg's which were obtained on extracts from vigorously aerated cultures.

The $\mathrm{E}_{\mathrm{a}}$ for cot-2 (45-I and 48-I) invertase in crude extracts was identical to that of wild type and had an experimental value of $9.7 \mathrm{kcal} / \mathrm{mol}$. Likewise, the $\mathrm{pH}$ optimum curves for the wild-type and cot-2(48-1) invertases were similar, with a broad range of activity between $\mathrm{pH} 4.0$ and $7^{\circ} 0$ and an optimum between 4.5 and 5.0 as reported by Metzenberg $($ I963a).

\section{Invertase chromatography and electrophoresis}

Elution patterns of wild-type and cot-2 invertase (crude extracts) from Sephadex G-200 (Fig. 3) revealed two peaks, the first corresponding to the tetramer, heavy invertase, and the second to its monomer, light invertase (Metzenberg, 1964). The data indicate a difference in the relative proportions of heavy and light invertase in cot-2 extracts from shake cultures as compared with wild type. Integration of the peak areas revealed that $68 \%$ of the cot-2 invertase was present as the heavy form, while the control strain had a broader peak of heavy invertase containing $57 \%$ of the total activity. In some experiments the overall shape of the curve of wild-type invertase was more like that of the cot-2 enzyme, but the wild-type invertase consistently had a smaller proportion of the heavy form. There were no reproducible differences in the time of elution between the cot-2 and wild-type enzymes, and when equal volumes of cot-2 and wild-type crude extracts were applied to the top of a column, the elution pattern showed no broadening of the activity peaks.

The increased proportion of heavy invertase from cot-2 grown in shake cultures was also apparent in acrylamide-gel disc electrophoresis. This increase was found with both the soluble and extracellular invertases (Fig. $4 a$ to $d$ ). Approximately $73 \%$ of the cot-2 soluble invertase was present as the tetramer, compared with $36 \%$ for the wild-type control. The extracellular invertases had 47 and $28 \%$, respectively, of their activity in the heavy form; they had a smaller fraction of the heavy form than found in the soluble invertases. A 
preponderance of the light form in the extracellular invertase is to be expected on the basis of fractionation at the cell wall as described by Trevithick \& Metzenberg (I966).

No significant differences were detected between the light/heavy ratios of the wild-type and cot-2 soluble invertases in crude extracts from bubble cultures (Fig. 4e,f). The migration rates $\left(R_{\mathrm{m}}\right)$ of the invertase forms of cot-2 and the wild type differed slightly.

\section{DISCUSSION}

After backcrossing cot-2 for seven generations, and after completing several of the biochemical comparisons, it was discovered that the cot-2 test strain (48-I) had apparently acquired some modifier gene(s) during the sixth backcross. We have presented the results from strain 48-I and several strains obtained earlier in the backcrossing protocol, and these show that in all characteristics except heat sensitivity, the invertases from the backcross progeny, including $48-\mathrm{I}$, are identical.

Most of the comparisons between cot-2 and wild-type invertase involved mycelium grown at $25{ }^{\circ} \mathrm{C}$, the permissive temperature. Except where otherwise required, the assays were conducted at a restrictive temperature $\left(37^{\circ} \mathrm{C}\right)$, but a permissive growth temperature was usually employed because at higher temperatures the cot-2 mycelium formed small, sticky balls that prevented the harvest of adequate amounts of mycelium. It is possible that biochemical comparisons between mycelia grown at higher temperatures would have shown larger differences between the respective enzymes. The change in the localization of cot-2 invertase (Table I) when cot-2 was grown at $34^{\circ} \mathrm{C}$ rather than $25^{\circ} \mathrm{C}$ supports this.

Most of the comparisons between the cot-2 and wild-type invertases were made using the soluble enzyme (itself a mixture of heavy and light forms). Those experiments (Table I; Fig. 4) which involved the wall-bound and extracellular invertases showed that the differences were not restricted to the soluble enzyme.

After the sixth backcross, cot-2 progeny (e.g. 47-I to 47-7) with an invertase of intermediate heat sensitivity were isolated. These strains probably do not represent segregation of the cot-2 locus from the gene responsible for the altered invertase because (i) a high proportion of the cot-2 strains isolated from the sixth backcross have intermediate heat sensitivity, (ii) the heat sensitivity is intermediate and only approaches that of wild-type invertase in the seventh backcross strains, and (iii) the cot-2 invertases of the sixth and seventh backcrosses still have an altered $K_{\mathrm{m}}$, heavy to light invertase ratio, and soluble to bound invertase ratio. We suggest that during the sixth and seventh backcrosses, modifier genes that primarily affect the heat sensitivity of invertase were incorporated through recombination into the strains that were isolated.

Recombination between the inv and cot-2 loci indicates that cot-2 does not play a role in determining the primary structure of the invertase subunit specified by the inv gene (Sargent \& Woodward, $1969 b$ ). There is evidence that Neurospora invertase may be composed of two non-identical subunits (Meachum, Colvin \& Braymer, I97I; H. D. Braymer, personal communication), so it is possible that cot-2 is the structural gene for the second subunit. A more plausible alternative is that the cot-2 gene alters the structure of invertase in a more indirect way, perhaps by changing the composition, quantity, or location of the carbohydrate known to be part of this enzyme (Meachum et al. 1971). This hypothesis is more compatible with the finding that under conditions (shake culture) that stimulate colonial growth of cot-2, the extracted enzyme is quite different from that of the wild-type strain, while under conditions (bubble culture) that stimulate 'wild-type' growth of cot-2, some of the differences, i.e. in $K_{\mathrm{m}}$ and light/heavy ratio, are no longer apparent (Table 4). If adequate 


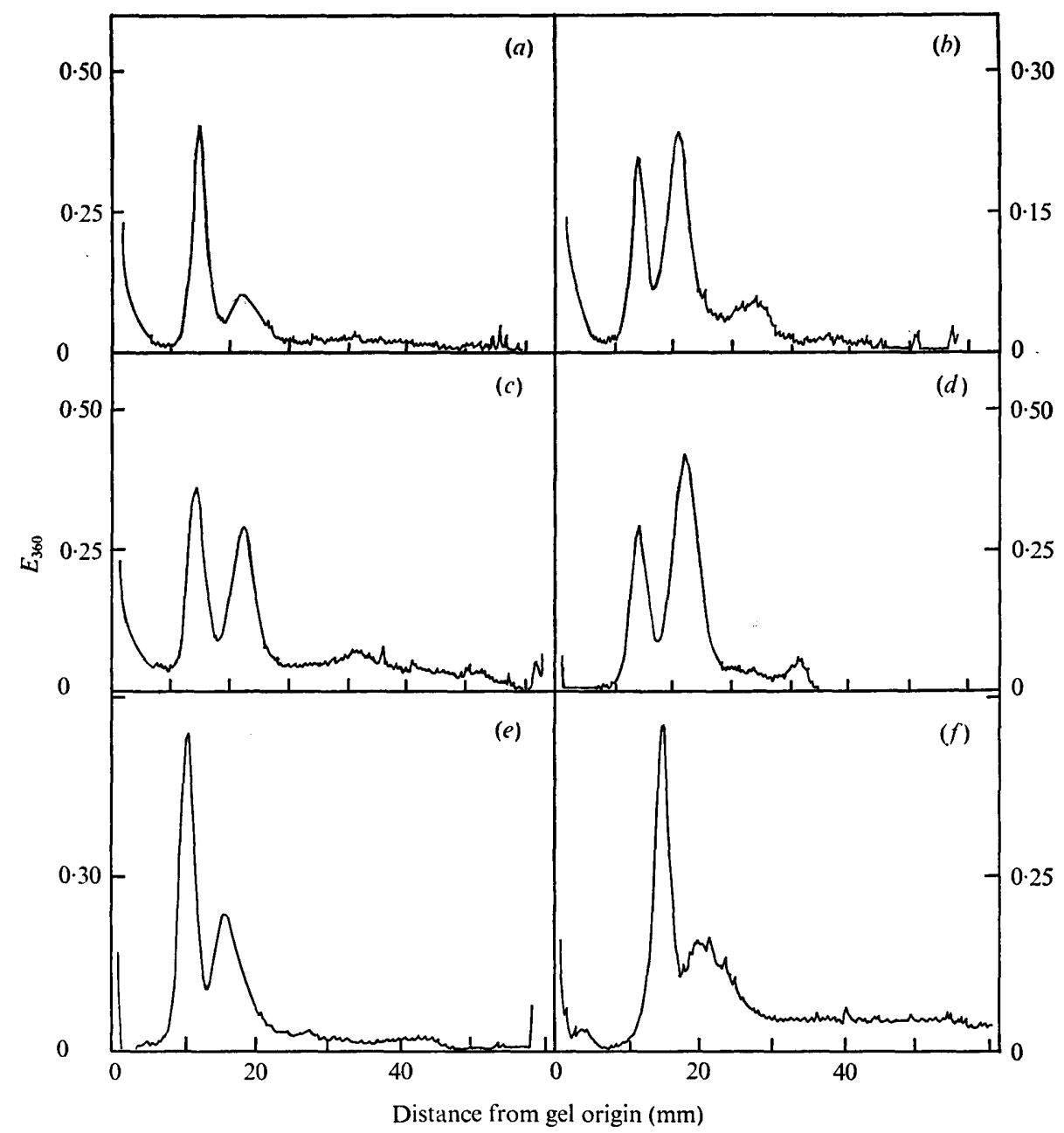

Fig. 4. Polyacrylamide gel patterns of wild type and cot-2 (48-1) invertase using tris-glycine buffer, $\mathrm{pH}$ 8.3. (a) Soluble invertase from cot-2 grown in shake culture; $(b)$ soluble invertase from wild type grown in shake culture; $(c)$ extracellular invertase from cot-2 grown in shake culture; $(d)$ extracellular invertase from wild type grown in shake culture; $(e)$ soluble invertase from cot-2 grown in bubble culture; $(f)$ soluble invertase from wild type grown in bubble culture. All cultures were grown at $25^{\circ} \mathrm{C}$.

Table 4. Summarized comparison of invertase from wild type and cot-2

\section{Characteristic}

Fraction wall bound ( $\%)$

Fraction extracellular $(\%)$

Activity after I h at $55^{\circ} \mathrm{C}(\%)$

$K_{\mathrm{m}}$ at $37^{\circ} \mathrm{C}(\mathrm{mm})$

$\mathrm{E}_{\mathrm{a}}(\mathrm{kcal} / \mathrm{mol})$

pH optimum

Fraction heavy form $(\%)$

Mobility of heavy form $\left(R_{\mathrm{m}}\right)$

\begin{tabular}{cc}
\multicolumn{2}{c}{ Shake culture } \\
\hline cot -2 & Wild type \\
75 & 87 \\
0.4 & 0.8 \\
4 & 52 \\
$7 \cdot 7$ & $5 \cdot 0$ \\
$9 \cdot 7$ & $9 \cdot 7$ \\
$\sim 5.0$ & $\sim 5 \cdot 0$ \\
73 & 36 \\
0.19 & 0.21
\end{tabular}

\begin{tabular}{|c|c|}
\hline \multicolumn{2}{|c|}{ Bubble culture } \\
\hline $\cot -2$ & Wild type \\
\hline 42 & 30 \\
\hline 21 & $3 \cdot 0$ \\
\hline 6.5 & $\overline{6 \cdot 4}$ \\
\hline- & - \\
\hline - & - \\
\hline 70 & 70 \\
\hline
\end{tabular}


amounts of the cot-2 invertase could be obtained the hypothesis could be tested directly by comparing the amino acid and carbohydrate content of the cot-2 and wild-type enzymes.

If the cot-2 gene somehow affects the structure of invertase, is this the primary function of the cot-2 gene or a result of other changes in metabolism, e.g. carbohydrate or cell-wall metabolism? Furthermore, if the primary function of the cot-2 gene is to affect invertase structure, how is the altered invertase responsible for the colonial morphology? Our data provide no direct evidence regarding these questions, but there are several lines of evidence that tie the enzyme invertase to the cell wall, and link the cell wall and its enzymes to fungal morphogenesis (Brody, 1973; Mahadevan \& Mahadkar, 1970; Ghosh, Montenecourt \& Lampen, 1973). It is known that fungal invertases have synthetic transferase activity (the Neurospora enzyme may be less active in this regard, however; Trevithick \& Metzenberg, 1964), that Neurospora invertase is physically associated with the cell wall (Metzenberg, 1963 $b$; Chung \& Trevithick, 1970; Chang \& Trevithick, 1972; Bigger, White \& Braymer, 1972), and that the inv mutant is morphologically abnormal (decreased conidiation) even when grown on glucose (Sargent \& Woodward, 1969a). Hopefully, further study will relate these facts to the specific mechanisms involved.

We express sincere appreciation to Christine L. Martens for help in the genetic crosses, J. M. Clark, Jun. for technical advice, H. D. Braymer and S. Brody for helpful suggestions concerning the manuscript, and M. L. Hochberg for advice and encouragement throughout. This work was supported by a grant (GM I654I) from the National Institutes of Health, and a summer fellowship (to C.E.) from the National Science Foundation.

\section{REFERENCES}

Abramsky, T., ScotT, W. A. \& TATUM, E. L. (1971). Neurospora morphology and 6-phosphogluconic acid dehydrogenase. Federation Proceedings 30, 1069 Abs (97).

Barry, E. G., Newmeyer, D., Perkins, D. D. \& Turner, B. C. (1972). Genetically determined round ascospores in N. crassa. Neurospora Newsletter 19, 17.

BigGeR, C. H., WhITE, M. R. \& BRAYMER, H. D. (I972). Ultrastructure and invertase secretion of the slime mutant of Neurospora crassa. Journal of General Microbiology 71, 159-166.

Brody, S. (1973). Metabolism, cell walls, and morphogenesis. In Developmental Regulation, pp. 107-154. Edited by S. J. Coward. New York: Academic Press.

BRody, S. \& TATUM, E. L. (1966). The primary biochemical effect of a morphological mutation in Neurospora crassa. Proceedings of the National Academy of Sciences of the United States of America 56, 1290-1297.

Brody, S. \& TATUM, E. L. (1967). Phosphoglucomutase mutants and morphological changes in Neurospora crassa. Proceedings of the National Academy of Sciences of the United States of America 58, 923-930.

Chang, P. L. Y. \& Trevithick, J. R. (1972). Distribution of wall-bound invertase during the asexual lifecycle of Neurospora crassa. Journal of General Microbiology 7o, 23-29.

Chung, P. L. Y. \& Trevithick, J. R. (1970). Biochemical and histochemical localization of invertase in Neurospora crassa during conidial germination and hyphal growth. Journal of Bacteriology 102, 423-429.

Crocken, B. J. \& NYC, J. F. (1964). Phospholipid variations in mutant strains of Neurospora crassa. Journal of Biological Chemistry 239, 1 727-1730.

Davis, B. J. (1964). Disc electrophoresis. II. Method and application to human serum proteins. Annals of the New York Academy of Sciences 121, 404-427.

DAVIS, R. H. \& DE SERRES, F. J. (1970). Genetic and microbiological research techniques for Neurospora crassa. Methods in Enzymology 17, 79-143.

EXPERimental Biochemistry (1964). Edited by J. M. Clark, Jun. San Francisco: W. H. Freeman.

Fuscaldo, K. E., LeChNeR, J. F. \& Bazinet, G. (I97I). Genetic and biochemical studies of the hexose monophosphate shunt in Neurospora crassa. I. The influence of genetic defects in the pathway on colonial morphology. Canadian Journal of Microbiology 17, 783-788. 
GABRIEL, O. \& WANG, S. F. (1969). Determination of enzymatic activity in polyacrylamide gels. I. Enzymes catalyzing the conversion of non-reducing substrates to reducing products. Analytical Biochemistry 27, 545-554.

GaRNJOBST, L. \& TATUM, E. L. (1967). A survey of new morphological mutants in Neurospora crassa. Genetics 57, 579-604.

Ghosh, B. K., Montenecourt, B. \& Lampen, J. O. (1973). Abnormal cell envelope ultrastructure of a Saccharomyces mutant with invertase formation resistant to hexoses. Journal of Bacteriology 116, $1412-1420$.

Lechner, J. F. \& Fuscaldo, K. E. (1969). Analysis of the 6-phosphogluconic dehydrogenase isozymes of Neurospora crassa. Bacteriological Proceedings I20, I8.

Lechner, J. F., Fuscaldo, K. E. \& Bazinet, G. (197I). Genetic and biochemical studies of the hexose monophosphate shunt in Neurospora crassa. II. Characterization of biochemical defects of the morphological mutants colonial 2 and colonial 3. Canadian Journal of Microbiology 17, 789-794.

Lowry, O. H., Rosebrough, N. J., Farr, A. L. \& Randall, R. J. (195I). Protein measurement with the Folin phenol reagent. Journal of Biological Chemistry 193, 265-275.

Mahadevan, P. R. \& MAhadkaR, U. R. (1970). The role of enzymes in growth and morphology of Neurospora crassa: cell-wall-bound enzymes and their possible role in branching. Journal of Bacteriology Ior, $94 \mathrm{I}-947$.

Meachum, Z. D., Jun., Colvin, H. J., Jun. \& Braymer, H. D. (I97I). Chemical and physical studies of Neurospora crassa invertase. Molecular weight, amino acid and carbohydrate composition, and quarternary structure. Biochemistry 10, 326-332.

MetZenberG, R. L. (1962). A gene affecting the repression of invertase and trehalase in Neurospora. Archives of Biochemistry and Biophysics 96, 468-474.

MetzenberG, R. L. (1963a). The purification and properties of invertase of Neurospora. Archives of Biochemistry and Biophysics 100, 503-5 Ir.

MetzenberG, R. L. (1963b). The localization of $\beta$-fructofuranosidase in Neurospora. Biochimica et biophysica acta 77, 455-465.

MetZenberG, R. L. (1964). Enzymically active subunits of Neurospora invertase. Biochimica et biophysica acta 89, 29I-302.

Mishra, N. C. \& TAtum, E. L. (1970). Phosphoglucomutase mutants of Neurospora sitophila and their relation to morphology. Proceedings of the National Academy of Sciences of the United States of America 66, 638-645.

Morgan, M. P., Garnjobst, L. \& TAtum, E. L. (1967). Linkage relations of new morphological mutants in linkage group V of Neurospora crassa. Genetics 57, 605-612.

Murayama, T. (1969). Biochemical and genetic studies on morphological change in a phosphohexoisomerase mutant of Neurospora. Japanese Journal of Genetics 44, 399.

Pina, E. \& TATUM, E. L. (1967). Inositol biosynthesis in Neurospora crassa. Biochimica et biophysica acta $\mathbf{1 3 6}$, 265-27I.

Sargent, M. L. \& Braymer, H. D. (I969). Selection of intramural-enzyme mutants. Neurospora Newsletter I4, I I-I 2.

SARGENT, M. L. \& WoodwARD, D. O. (1969a). Genetic determinants of circadian rhythmicity in Neurospora. Journal of Bacteriology 97, 86I-866.

Sargent, M. L. \& Woodward, D. O. (1969b). Gene-enzyme relationships in Neurospora invertase. Journal of Bacteriology 97, 867-872.

Scarborough, G. A. \& Nyc, J.F. (I967). Properties of a phosphatidylmonomethylethanolamine $N$ methyltransferase from Neurospora crassa. Biochimica et biophysica acta 146, I I I-I I9.

ScotT, W. A. \& TATUM, E. L. (I970). Glucose-6-phosphate dehydrogenase and Neurospora morphology. Proceedings of the National Academy of Sciences of the United States of America 66, 515-522.

SoMOGYI, M. (1952). Notes on sugar determination. Journal of Biological Chemistry 195, 19-23.

Trevithick, J. R. \& Metzenberg, R. L. (1964). Kinetics of the inhibition of Neurospora invertase by products and aniline. Archives of Biochemistry and Biophysics 106, 260-270.

Trevithick, J. R. \& MetzenberG, R. L. (I966). Molecular sieving by Neurospora cell walls during secretion of invertase isozymes. Journal of Bacteriology $\mathbf{9 2}$, IOIO-IOI5.

Vogel, H. J. (1964). Distribution of lysine pathways among fungi: evolutionary implications. American Naturalist 98, 435-446. 